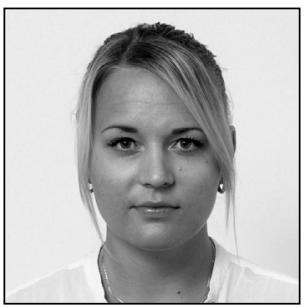

Kärt Pormeister

Magister artium

\title{
The Legal Concept of Slavery in the Modern European Legal Sphere
}

\section{Introduction}

Slavery as a legal concept has seemingly lost its relevance in the modern European ${ }^{*_{2}}$ legal sphere, with the term 'slavery' being thought to point to an archaic concept. However, developments of the last decade indicate otherwise. In 2001 and 2002, the International Criminal Tribunal for the former Yugoslavia (ICTY) dissected the legal concept of slavery in order to determine the applicability of the prohibition of enslavement in modern circumstances. ${ }^{* 3}$ The term 'slavery' was also incorporated into the Statute of the International Criminal Court (ICC) in 2002. ${ }^{*}$ Then, in 2005, the European Court of Human Rights (ECtHR) analysed the meaning of slavery within the meaning of Article 4 of the European Convention for the Protection of Human Rights and Fundamental Freedoms (ECHR). ${ }^{*}$ It follows from these developments that the concept of slavery cannot have lost its relevance. On the contrary, slavery is even an ever more serious problem of modern society rather than an archaic concept. ${ }^{*}$ However, not all abuses of a person's integrity and right to self-determination amount to slavery. The question of what practices correspond to the contemporary legal

1 The article is based on the author's master's thesis written and defended in 2013 at the University of Tartu. The original work is written in Estonian.

2 For the purpose of the article, the European legal sphere is defined as consisting of the 47 member states of the Council of Europe. The focus on the modern concept of slavery solely in the European legal sphere is intended to narrow the object of the article in consideration of the fact that, first of all, the modern legal concept of slavery cannot reasonably be expected to be on the same level globally. In Europe, the legal approach to human rights is extremely progressive in a global comparison. Secondly, the historical concept of slavery differs somewhat amongst Western states, particularly between Europe and the United States. For the latter, the concept of slavery had a complex intra-territorial relevance, whereas for European states in the recent centuries slavery had first and foremost been a colonial matter and, accordingly, slavery was initially more of an extraterritorial concept. In consequence, the academic debate addressing the legal concept of slavery and the evolution thereof can hardly be compared between these two parts of the world, certainly not within the capacity of one article.

3 ICTY (Trial Chamber) judgement of 22.2.2001, Case IT-96-23-T\&IT-96-23/1-T, Prosecutor v. Dragoljub Kunarac, Radomir Kovac and Zoran Vukovic; ICTY (Appeals Chamber) judgement of 12.6.2002, Case IT-96-23\&IT-96-23/1-A, Prosecutor $v$. Dragoljub Kunarac, Radomir Kovac and Zoran Vukovic.

4 Rome Statute of the International Criminal Court (adopted on 17 July 1998 and entering into force on 1 July 2002) - 2187 UNTS 3 .

5 ECtHR judgement of 26.7.2005, Application 73316/o1, case of Siliadin v. France, Reports of Judgments and Decisions 2005-VII.

6 Today, the trade in human beings is referred to frequently as human trafficking. According to Eurostat's 2013 report on 'trafficking in human beings', the number of cases of human trafficking increased by $18 \%$ from 2008 to 2010, reaching nearly 10,000 victims by 2010. The report is available at http://ec.europa.eu/dgs/home-affairs/what-is-new/news/ news/2013/docs/20130415_thb_stats_report_en.pdf (most recently accessed on 12.2.2014). 
concept of slavery in Europe has raised controversy because of conflicting opinions of recognised scholars, tribunals, and courts. The present article is written to shed light on the contemporary approach to the legal concept of slavery in Europe by applying an evolutionary approach.

\section{The historical legal concept of slavery in Europe}

The historical concept of slavery in Europe comprised foremost the exploitation of indigenous peoples in the African colonies of the great powers of Europe. ${ }^{* 7}$ During the Atlantic slave trade, which began in the mid-15th century and continued until the second half of the 19th century, an estimated 11 million people were transported across the Atlantic Ocean, a practice that continued until the anti-slavery movements gained ground in the 19th century. ${ }^{*}$ The first anti-slavery movements are considered to have emerged after the Napoleonic wars, fairly early in the 1800s. ${ }^{*}{ }^{9}$ The Congress of Vienna (1814-1815), the Berlin Conference (1884-1885), and the Brussels Conference (1889-1890) are regarded as the most noteworthy historical events in the development of the international anti-slavery movement in 19th-century Europe ${ }^{{ }^{*} 10}$-all of which came together to result in the adoption of declaratory acts with certain restrictions pertaining to the slave trade ${ }^{* 11}$. These restrictions, however, were aimed first and foremost at balancing the economic interests of conflicting colonial powers. Actual abolition of the slave trade was first incorporated into a binding international convention in the Treaty of Saint-Germain-en-Laye, in 1919. ${ }^{*}$ On the initiative of the British, the latter led to the adoption of the first international instrument enacted for the abolition of not only practising of the slave trade but slavery itself. The Slavery, Servitude, Forced Labour and Similar Institutions and Practices Convention was adopted by the League of Nations in 1926, also referred to as the Slavery Convention of $1926 .{ }^{*} 13$

It is in the Slavery Convention of 1926 that the first legal definition of slavery and enslavement can be found. Article 1 of this convention defines slavery as 'the status or condition of a person over whom any or all of the powers attaching to the right of ownership are exercised'. Later, the Slavery Convention of 1926 was supplemented by the UN's 1956 Supplementary Convention on the Abolition of Slavery, the Slave Trade, and Institutions and Practices Similar to Slavery (or 'the 1956 Supplementary Convention'). ${ }^{*} 4$ Article 1 of the 1956 Supplementary Convention listed practices that were to be abolished by the member states, adding that the terms applied 'whether or not [these were] covered by the definition of slavery contained in article 1 of the Slavery Convention signed at Geneva on 25 September 1926'. Article 1 of the 1956 Supplementary Convention listed practices such as debt bondage, serfdom, practices of selling women into marriage or doing the equivalent with family members, and the practice of inheriting widowed women, while also covering practices whereby children are given away for the purpose of exploiting them. The question of whether the Slavery Convention of 1926 covered practices other than chattel slavery (i.e., de jure ownership

T. Burnard, G. Heuman (eds). The Routledge History of Slavery. Abingdon: Routledge 2011, p. 80.

8 J.P. Rodriguez (ed.). The Historical Encyclopedia of World Slavery, Vol. 1 (A-K). Santa Barbara, California: ABC-CLIO 1997, p. xx.

9 S. Zimmermann. The long-term trajectory of anti-slavery in international politics: From the expansion of the European international system to unequal international development. - M. van der Linden (ed.) Humanitarian Intervention and Changing Labor Relations: The Long-term Consequences of the Abolition of the Slave Trade. Leiden, The Netherlands: BRILL 2010, p. 449.

$10 \quad$ Ibid., p. 663.

11 Act XV, Declaration of the Powers, on the Abolition of the Slave Trade, of the 8th of February, 1815. - Lewis Hertslet (ed.). A Complete Collection of the Treaties and Conventions, and Reciprocal Regulations at Present Subsisting Between Great Britain and Foreign Powers, and of the Laws, Decrees, and Orders in Council, Concerning the Same; [...], Vol. 1. London 1840, p. 9ff.; General Act of the Conference of Berlin Concerning the Congo. - The American Journal of International Law 3 (1909)/1, Supplement: Official, pp. 7-25; General Act of the Brussels Conference Relative to the African Slave Trade, signed in Brussels on 2 July 1890, printed by Harrison and Sons in 1892.

12 S. Miers. Slavery in the Twentieth Century: The Evolution of a Global Problem. Walnut Creek, California: AltaMira Press 2003, p. 61.

13 Slavery, Servitude, Forced Labour and Similar Institutions and Practices Convention of 1926 (Slavery Convention of 1926), adopted on 25 September 1926 and entering into force on 9 March 1927 - 6o L.N.T.S. 253.

14 Supplementary Convention on the Abolition of Slavery, the Slave Trade, and Institutions and Practices Similar to Slavery, adopted on 7 September 1956 and entering into force on 30 April 1957 - 226 U.N.T.S. 3. 
of another person) and whether the 1956 Supplementary Convention confirmed or overruled the latter assumption has led to much debate among academics in the field of law.

In 2008, Jean Allain published a book based on the travaux préparatoires of the 1926 and 1956 slavery conventions. ${ }^{*} 15$ In this work, Allain seemed to be arguing that it was not the original intention of the signatories to the 1926 convention for its first article to encompass any other practices than chattel slavery. ${ }^{*} 16$ However, in other works, ${ }^{*}{ }^{*}$ Allain seems to agree that the Slavery Convention of 1926 also had to cover de facto ownership over people, rather than merely de jure ownership that characterised chattel slavery. ${ }^{*} 18$ The Secretary-General of the United Nations has explained in one of his memoranda that the wording of Article 1 of the 1956 Supplementary Convention was intended to accept the differences in opinion with respect to the scope of the definition of slavery in the 1926 convention (by accepting that the practices listed in the 1956 Supplementary Convention might or might not have been already covered by the Slavery Convention of 1926). ${ }^{* 19}$

Modern legal scholars, however, can be deemed to have come to consensus by agreeing that the 1926 definition of slavery encompassed more than de jure ownership of people. ${ }^{* 0}$ The remaining difference in opinion is in the argued extent of de facto ownership. Some authors, Allain among them, argue that certain of the practices listed in the 1956 Supplementary Convention must be defined as servitude while only those entailing de facto ownership over another person can be defined as slavery. ${ }^{* 21}$ This argument is questionable insofar as, even historically, most practices listed in the 1956 Supplementary Convention (all of them in the context of modern society) essentially encompass the de facto exercise of some powers attached to the right of ownership over another person.

It can be concluded that even if the 1926 definition of slavery was meant to encompass only chattel slavery, it must be taken into account that the Slavery Convention of 1926 still was designed to regulate colonial matters. Accordingly, its aims did not include regulating intra-territorial matters as later regional conventions (such as the ECHR) did. Notwithstanding the therefore seemingly ${ }^{{ }^{2} 22}$ somewhat limited relevance of the scope of the 1926 definition of slavery in terms of an evolutionary approach, it must be noted that the wording of Article 1 of the 1926 convention allows next to no room for doubt of the assertion that the definition of slavery in Article 1 was meant to encompass more than merely chattel slavery. First of all, the language 'the status or condition' indicates that the legal status of a slave was not a precondition for slavery within its meaning in the Slavery Convention of 1926 (leaving as it does the option 'condition'). This is further supported by the other part of the definition: 'a person over whom any or all of the powers attaching to the right of ownership are exercised'. The wording 'any of the powers' indicates that the person in question did not need to be entirely reduced to having the status of an object in order to be covered by Article 1 of the 1926 convention.

If the 1926 definition of slavery indeed already covered de facto ownership of another person, the question remains of what practices would have at that point in time amounted to de facto ownership. In answering this question, one must take several factors into account. Firstly, the above-mentioned limited intraterritorial effect of the Slavery Convention of 1926 must be recalled. Secondly, the concept of human rights had not been developing as progressively as it did after World War II. ${ }^{{ }^{23}}$ Thirdly, one must look at states'

15 J. Allain. The Slavery Conventions: The Travaux Préparatoires of the 1926 League of Nations Convention and the 1956 United Nations Convention. Leiden, The Netherlands: BRILL 2008. - DOI: http://dx.doi.org/10.1163/ ej.9789004158610.1-841.

16 Ibid., pp. 9, 59.

17 J. Allain. The definition of 'slavery' in general international law and the crime of enslavement within the Rome Statute. - Guest Lecture Series of the Office of the Prosecutor. The Hague, The Netherlands: ICC-CPI individual authors 2007, pp. 12-13.

18 Ibid., pp. 3, 11-12.

19 ECOSOC. The Draft Supplementary Convention of Slavery and Servitude Submitted by the Government of the United Kingdom and Comments Thereon (Memorandum of the Secretary-General), UN Doc. A/C.43/L.1, 2.12.1995, p. 22.

20 N.L. McGeehan. Misunderstood and neglected: The marginalisation of slavery in international law. - The International Journal of Human Rights 16(2012)/3, p. 444. See also Office of the United Nations High Commissioner for Human Rights. Abolishing Slavery and Its Contemporary Forms, UN Doc. HR/PUB/02/4, D. Weissbrodt and Anti-Slavery International. New York and Geneva 2002, p. 5.

21 J. Allain (see Note 15), p. 59.

22 At the start of the 21st century, both the ICTY and the ECtHR turned to, inter alia, the 1926 slavery convention for the definition of slavery, thereby re-establishing its relevance.

23 The aftermath of World War II is seen as an era that served as a catalyst for the international human rights movements. See, for example, J. Morsink. The Universal Declaration of Human Rights: Origins, Drafting, and Intent. Philadelphia: 
economic considerations with regard to slavery in the colonial territories-i.e., what practices could reasonably have been abolished at that point in time in colonial territories-while taking into account cultural and historical factors in those colonial territories just as fully.

\section{Slavery in the modern European legal sphere}

In the modern European legal sphere, the term 'slavery' can be found in numerous international instruments-inter alia, the Statute of the International Criminal Court ${ }^{* 24}$, the latter being the only modern international legal instrument that actually defines enslavement. It is important to note that, in Article 7 , paragraph 2(c), the Statute of the ICC includes, expressis verbis, human trafficking in the definition of slavery, emphasising the trafficking in women and children (thus expressly bringing the term 'slavery' into the modern day in line with contemporary practices and circumstances). Although the Statute of the ICC deals with slavery as a crime against humanity and, in doing so, sets as preconditions for the applicability of the concept of enslavement both for the actions to take place as a part of a systematic attack against civilisation and for the perpetrator to have knowledge of the attack, it does not bear relevance with respect to the core elements of enslavement as such, the latter being de facto ownership of another person, such as is entailed in the case of human trafficking.

The word 'slavery' can also be found in the United Nations Universal Declaration of Human Rights $(\mathrm{UDHR})^{*^{2} 5}$, the International Covenant on Civil and Political Rights (ICCPR) ${ }^{{ }_{2}}{ }^{26}$, and the European Convention for the Protection of Human Rights and Fundamental Freedoms ${ }^{*}{ }^{27}$. None of these three define slavery, and both the ICCPR and the ECHR follow the wording of the prohibition of slavery in the UDHR. It must be noted that Article 8 of the ICCPR systematically differentiates between slavery and servitude, with these two concepts being separated into two paragraphs. The Commentary to the Drafts for the ICCPR confirms that it was the intent of the drafters of the ICCPR to separate the concepts of slavery and servitude and that the division with separate paragraphs was developed accordingly. ${ }^{* 28}$ Some argued that human trafficking should be included in the first paragraph prohibiting slavery and the slave trade. This proposal was turned down, as the drafters had the intent of expressly addressing only chattel slavery and the accompanying slave trade in the first paragraph of Article 8. ${ }^{* 2}$ The second paragraph of Article 8, that prohibiting servitude, was meant to include all other practices, similar to slavery, that entail dominance of one man over another without the latter actually losing the legal status of a free man. ${ }^{*} 30$

In 2002, however, the monitoring body of the ICCPR, the UN Human Rights Committee (UNHRC), stated in its General Comment No. 28, pertaining to the non-discrimination-oriented Article 3 of the ICCPR, that under Article 8 of the ICCPR the member states bear the obligation to take measures 'to eliminate trafficking of women and children, within the country or across borders, and forced prostitution.. ${ }^{*}{ }^{1}$ The UNHRC added that all member states must also provide information on measures taken 'to protect women and children, including foreign women and children, from slavery, disguised, inter alia, as domestic or other kinds of personal service'. Regrettably, the UNHRC has not published a General Comment dealing exclusively with Article 8 and slavery. However, with the statement made in the General Comment to Article 3 , the UNHRC left little doubt as to whether slavery within the meaning of Article 8 of the ICCPR is still limited to chattel slavery and de jure ownership of another person as it had historically been understood

University of Pennsylvania Press 1999, p. 36 ff.; J. Donnelly. International human rights: A regime analysis. - International Organization 40(1986)/3, p. 614ff.

24 Rome Statute of the International Criminal Court (adopted on 17 July 1998 and entering into force on 1 July 2002) - 2187 U.N.T.S. 3 .

25 Universal Declaration of Human Rights, UN Doc. A/RES/3/217 A, 10.12.1948.

26 International Covenant on Civil and Political Rights, adopted on 16 December 1966 and entering into force on 23 March 1976 - 999 U.N.T.S. 171.

27 Convention for the Protection of Human Rights and Fundamental Freedoms (adopted on 4 November 1950 and entering into force on 3 September 1953) - 213 U.N.T.S. 222.

28 Secretary-General of the UN. Commentary on the Drafts for the ICCPR. 1955, UN Doc. A.2929, pp. 102-107.

29 Ibid., Section 17.

$30 \quad$ Ibid., Section 18.

31 Equality of rights between men and women, Article 3, 29.3.200o. UN Doc. CCPR/C/21/Rev.1/Add.10, General Comment No. 28 (General Comments). 
to be. By accepting that slavery can exist in disguised forms, the UNHRC accepted that the modern legal concept of slavery codified in Article 8 of the ICCPR in its paragraph 1 encompasses other forms of slavery than purely chattel slavery.

In 2001 and 2002, in their judgements in the case of Kunarac et al. ${ }^{*}{ }^{32}$, both the Trial Chamber and the Appeals Chamber of the ICTY conducted a thorough analysis of the legal concept of slavery in European history. The ICTY too came to the conclusion that even in 1926 the concept of slavery had to extend to more than just traditional chattel slavery. The ICTY proposed a non-exhaustive list of criteria to be considered in determination of whether specific practices amount to enslavement. The list of criteria included 'control of someone's movement, control of physical environment, psychological control, measures taken to prevent or deter escape, force, threat of force or coercion, duration, assertion of exclusivity, subjection to cruel treatment and abuse, control of sexuality and forced labour. ${ }^{*}{ }^{33}$

In a surprising contrast to the UNHRC and the ICTY, the ECtHR came to a different conclusion in its 2005 judgement in Siliadin $v$. France ${ }^{*} 34$ when considering the modern legal concept of slavery codified in Article 4 of the ECHR. As the ICTY did, the ECtHR referred to the Slavery Convention of 1926; however, the ECtHR noted that the 1926 definition of slavery corresponds to the 'classic' meaning of slavery as it was practised for centuries. The ECtHR found that enslavement presupposes depriving a person of his personal autonomy and 'exercising a genuine legal right of ownership' over that person. The Court concluded that the applicant had been kept in servitude but not in slavery. Servitude was defined here as a particularly serious form of denial of freedom, one that, in addition to the obligation to perform certain services for others, entails the obligation for the serf to live on another person's property and the impossibility of altering his condition. ${ }^{*} 35$ Thus, unlike the UNHRC, the ICTY, and the definition given for slavery in the Statute of the ICC, and, arguably, contrary to the 1926 and 1956 slavery conventions, the ECtHR defined slavery as being limited to de jure ownership of another person, with reference to historical chattel slavery. The ECtHR has yet to give an explanation for or comment on the general need to differentiate between servitude and slavery ${ }^{*}{ }^{36}$, since, unlike in the ICCPR, these two concepts are dealt with in the same paragraph of Article 4 of the ECHR, and both are non-derogable under Article 15, paragraph 2 of the same convention. The differentiating approach of the ECtHR has been heavily criticised ${ }^{*} 37$-in this author's view, rightly so-because there is no historical or contemporary legal basis or practical need for such differentiation.

Later, in 2010, the ECtHR dealt with human trafficking in its judgement in Rantsev v. Cyprus and Russia $^{*}{ }^{3}$. The Rantsev judgement can be deemed to be one of the most controversial, if not contradictory, judgements of the ECtHR in the last decade. The Court noted, inter alia, that the Rantsev case was, as the Siliadin case was, one dealing with human trafficking, although in the Siliadin judgement the Court never addressed the issue of human trafficking. What is more, the Court referred to the judgement of the Appeals Chamber of the ICTY in Kunarac et al., in which the latter had defined slavery as entailing more than what the ECtHR had accepted in Siliadin. The ECtHR did not express its opinion on the ICTY judgement but nonetheless included its core theoretical approach in the Rantsev judgement. The ECtHR then considered the fact that 'trafficking in human beings, by its very nature and aim of exploitation, is based on the exercise of powers attaching to the right of ownership. It treats human beings as commodities to be bought and sold and put to forced labour, often for little or no payment, usually in the sex industry but also elsewhere', language that corresponds to the definition of slavery in the Slavery Convention of 1926. Therefore, an obvious question arises: did the ECtHR finally accept that slavery can exist in other forms than chattel slavery? That is, did it conclude that the concept of slavery covers human trafficking, which entails de facto but not de jure ownership of another person (with the latter being legally precluded in all member states of the Council of Europe)? Regrettably, the ECtHR did not further explain what it meant with the quoted statement. Instead,

2 See Note 3 .

33 Ibid., Trial Chamber judgement of 22.2.2001, Section 543, repeated in the Appeals Chamber judgement of 12.6.2002, Section 24.

$34 \quad$ See Note 5 .

35 Ibid., Section 122.

36 ECtHR judgement of 7.1.2010, Application 25965/04, case of Rantsev v. Cyprus and Russia, Reports of Judgments and Decisions 2010. Setting aside the comment in the case Rantsev $v$. Cyprus and Russia regarding the fact that, in terms of human trafficking falling within the scope of Article 4 of the ECHR, there is no need to differentiate between these two concepts.

37 See, for example, N.L. McGeehan (see Note 20), full article.

38 ECtHR judgement of 7.1.2010, Application 25965/04, case of Rantsev v. Cyprus and Russia, Reports of Judgments and Decisions 2010. 
the Court found that in the case of human trafficking there was no need to differentiate among slavery, servitude, and forced or compulsory labour, as human trafficking is clearly contrary to the meaning and purpose of Article 4 of the ECHR. ${ }^{*} 39$ In this regard, the Court's approach must be celebrated, since adherence to technicalities of the law should not be a purpose in itself, especially when human rights are at issue.

In the case law following the Rantsev judgement, the ECtHR, having seemingly forgone the differentiating approach, still went on to refer to its positions in Siliadin. ${ }^{*} 40$ This must be deemed quite contradictory, since the Court had found in the Rantsev judgement that the Siliadin case too was related to human trafficking, then, in turn, concluded in the judgement in C.N. and V.v. France ${ }^{* 41}$ that the latter had more in common with the Siliadin case rather than the Rantsev case. In other words, having set aside the differentiating approach in Rantsev, the Court nevertheless used that approach in later cases, ones that it (though arguably indirectly) found to be similar to the Rantsev case.

Although the ECtHR has yet to set aside its theoretical differentiating approach established in Siliadin, the principle of the ECHR being a living instrument ${ }^{*} 42$ leaves room for improvement and allows one to assume that the ECtHR will eventually follow other international legal authorities in Europe in accepting that the legal concept of slavery has evolved beyond chattel slavery, if it can even be said to have ever been confined to such narrow limits (given that even serfdom did not amount to de jure ownership of another person). It must be emphasised that the ECtHR has made clear in its case law that the ultimate goal of the ECHR is to ensure the protection of human rights to the highest possible standards and that those standards rise in tandem with societal development. ${ }^{*} 3$ In light of this, it cannot be accepted that the ECHR covers the prohibition of slavery only as an outdated and archaic concept, one that has no relevance in the contemporary European legal sphere. Accordingly, the concept of slavery within the meaning of Article 4 of the ECHR must be deemed to encompass more than merely de jure ownership over another person.

\section{Conclusions}

It can be concluded that the legal definition of slavery as involving de facto ownership of another person per se has not changed since the signing of the Slavery Convention of 1926. However, its practical effect has moved beyond the social and economic circumstances of the early 2oth century. The understanding of what constitutes de facto ownership of another person has evolved side by side with societal changes; one of the most important factors here being the events that took place during World War II. The latter events are deemed to have been the starting point of the progressive approach to human rights that has now become one of the most important hallmarks of Europe (at least in the legal sphere).

It must be emphasised that three distinct stages in the evolution of the concept of slavery can be delineated. The first is that of the early 20th century and the Slavery Convention of 1926, which was aimed at abolishing slavery and the slave trade as it manifested itself in the colonial territories and with an emphasis on the historic Atlantic slave trade. In that era, the prohibition of slavery had little intra-territorial meaning in continental Europe. In the middle of the 2oth century, World War II marks the beginning of the second stage of development, during which human rights instruments were drafted to deal with specific issues of continental Europe and in mindfulness of the atrocities of the war. Therefore, it can be argued that the UDHR, the ECHR, and the ICCPR initially also addressed traditional slavery, since one could easily argue that it had been exercised during the war to the disadvantage of certain social groups. The third stage can be said to have begun after the Cold War and in the years following the collapse of the USSR. That stage began in the late 2oth century and extends to the present day. The contemporary international legal system can be said to be divided in the way that international criminal law deals with extreme matters such as systematic enslavement, whereas human rights law in Europe generally concerns individual cases (although they might have a systematic dimension, as seen in Rantsev). When one remembers that legal ownership of another person is not possible-except in extreme situations, such as wars, which are dealt

39 Ibid., Sections 277-281.

40 See, for example, the ECtHR judgement of 11.10.2012, Application 67724/o9, case of C.N. and V.v. France.

41 Ibid.

42 See, for example, the ECtHR judgement of 25.4.1978, Application 5856/72, case of Tyrer v. The United Kingdom, Series A-26, Section 31.

43 Ibid. 
with in international criminal law-the concept of slavery in human rights law in the European legal sphere cannot but address de facto ownership of another person, slavery in less extreme terms than the historical.

For determination of what must be understood to be de facto ownership of another person in contemporary terms, the list of criteria set forth by the ICTY can be deemed most suitable. Being non-exhaustive, this list is flexible enough to allow the prohibition of slavery to be used for purposes of employing the strictest approach and thereby reaching the highest possible standard of protection of human rights-which, after all, is what has been determined by the ECtHR to be the ultimate goal of the central human rights protection instrument, the ECHR. 